\title{
SLOTERDIJK: NEUROGLOBALIZACIÓN, ESTRESORES Y PRÁCTICAS PSICO-INMUNOLÓGICAS
}

\author{
Adolfo Vásquez Rocca \\ Universidad Andrés Bello UNAB - Universidad Complutense de Madrid
}

http://dx.doi.org/10.5209/rev_NOMA.2012.v35.n3.42209

Resumen.- Se indaga el programa general encaminado a la experimentación con el propio cuerpo, método que encuentra sus fundamentos en la idea de la medicina romántica donde, según Sloterdijk, los efectos de las dosis en el hombre sano y el enfermo se reflejaban de manera especular. Es aquí donde se origina una ambiciosa semiótica de la medicación farmacológica, no sólo del endomorfinismo de la especulación, sino también de mecanismos endocrinos o quimioéticos.

En la esfera humana existen no menos de tres sistemas inmunitarios, los cuales trabajan superpuestos, con un fuerte ensamblaje cooperativo y una complementariedad funcional. Sobre el sustrato biológico, en gran parte automatizado e independiente de la conciencia, se han ido desarrollando en el hombre, en el transcurso de su desarrollo mental y sociocultural, dos sistemas complementarios encargados de una elaboración previsora de los daños potenciales: por un lado, un sistema de prácticas socio-inmunitarias, especialmente las jurídicas o las solidarias, pero también las militares, con las que los hombres desarrollan, en la "sociedad", sus confrontaciones con agresores ajenos y lejanos y con vecinos ofensores o dañinos; por otro lado, un sistema de prácticas simbólicas, o bien psico-inmunológicas, con cuya ayuda los hombres logran, desde tiempos inmemoriales, sobrellevar más o menos bien su vulnerabilidad ante el destino, incluida la mortalidad, a base de antelaciones imaginarias y del uso de una serie de armas mentales.

Palabras clave.- inmunología, comunicaciones, antropotécnicas, biopolítica, neuroglobalización 


\title{
Sloterdijk; neuroglobalización, stressors and psycho-immunological practices
}

\begin{abstract}
We explore the comprehensive program to experiment with one's body, a method that finds its basis in the idea of romantic medicine where, according to Sloterdijk, the dose effects in the healthy and the sick were reflected in a mirror. This is where an ambitious originates semiotics of pharmacological medication, not only endomorfinismo of speculation, but quimioéticos endocrine mechanisms.

In the human sphere there are no less than three immune systems, which work overlaid with a strong cooperative assembly and functional complementarity. On the biological substrate, largely automated and independent of consciousness, have been developed in man, in the course of their mental and sociocultural, two supplementary charge of a proactive development of potential damages: first, a system of socio-immune practices, especially legal or solidarity, but also the military, with which men develop, in "society", their confrontations with foreign aggressors and distant neighbors and offenders or harmful, on the other hand, a system of symbolic practices or psycho-immunological, with whose help men succeed, since time immemorial, coping fairly well their vulnerability to the destination, including mortality, based on imaginary antelaciones and use of a series mental arms.
\end{abstract}

Keywords.- $\quad$ immunology, communications, anthropotechnics, biopolitics, neuroglobalización

\section{1.- Concierto de transferencias e historia de la fascinación de proximidad}

Expondré -siguiendo el plan de la trilogía Esferas- ${ }^{1}$ la constitución antropológica de las comunicaciones. Toda historia de los medios es una historia de las transferencias de pensamientos. Los seres humanos agitados componen un concierto de vinculaciones convirtiéndose ellos mismos en operadores de múltiples influjos creadores. Lo que el siglo XVI los europeos llaman magología es a la acción del hombre mental y espiritualmente abierto al mundo, que se ejercita para cooperar con las acciones y efectos recíprocos discretos entre las cosas en un universo altamente comunicativo. Discretas obsesiones telecomunicativas que habían Ilamado la atención de Freud, pero que el creador del psicoanálisis -según Sloterdijk- con buen juicio, mantuvo en secreto evitando hacer proclamaciones ruidosas $^{2}$; sabía que hubiera sido fatal para el destino científico-clínico del movimiento psicoanalítico que él lo hubiera implicado en una batalla cultural entre modelos de comunicación oculto-arcaicos y modelos-ilustrados. Era consciente de que la suerte del psicoanálisis como disciplina científica que trata con las relaciones de proximidad en un marco epistemológico específicamente moderno,

1 SLOTERDIJK, Peter, Esferas I - II - III; la trilogía Esferas es, sin duda, el opus mágnum de Peter Sloterdijk.

Esferas I: Burbujas. Microsferología (1998); Madrid; Siruela, 2003.

Esferas II: Globos. Macrosferología (1999); Madrid; Siruela; 2004

Esferas III: Espumas. Esferología Plural (2004); Madrid; Siruela; 2006.

SLOTERDIJK, Peter, Esferas I, Ediciones Siruela, Madrid, 2003, p. 249 
estaba sólo en su alianza con la Ilustración, esto es encaminándolo por el camino seguro de la ciencia, ocultando cualquier pasado ocultista o magológico como el mesmerismo, de modo que todo este largo pasado de efectos participativos preverbales se convertirían en los secretos bizarros del psicoanálisis original.

¿Qué otra cosa pueden ser los medios, sino el espacio de tránsito periódico de mensajes, remitentes, canales y lenguas? Esto es "una ciencia general de la visitabilidad de algo por algo"3. En adelante intentaré mostrar que la teoría de los medios ${ }^{4}$ y la teoría de las esferas convergen precisamente en esta teoría de la visitabilidad, a la que Sloterdijk también denomina contagios afectivos.

Y esto es precisamente lo que Sloterdijk profundiza en su Artículo Actio in Distans, cuando describe del siguiente modo el plan de esta investigación:

"A continuación me voy a limitar a explicar algunas observaciones sobre el segundo foco del debate mediático-teórico. Quisiera reunir una serie de observaciones alrededor de las siguientes preguntas: ¿qué es lo que hacen unos medios con otros? y ¿cuáles son las formas de cooperación que surgen a nivel inter-aparático e inter-programático? Referente a este asunto se puede intuir cuál es la relación entre la dimensión de lo inter-aparático con la dimensión de lo intersubjetivo. Lo que será decisivo en este contexto es cómo se modifica la forma de la subjetividad mediante las tele-funciones. Como lo anuncié, no estoy intentando un acceso directo a los fenómenos, sino que los discuto indirectamente a través del enajenamiento metafísico, que, a su vez, se transforma en enajenamiento arqueológico o paleológico" 5 .

\section{SLOTERDIJK, Peter, Esferas I. Burbujas, Ediciones Siruela, Madrid, 2003, p. 39}

4 Mientras los llamados "mass-media" roban masivamente a los seres humanos sus propiedades mediales, estos desarrollan los signos característicos del "último hombre" en el peor sentido de la expresión. Vivimos dentro de nosotros mismos la larga agonía del ángel. Los últimos hombres son "ángeles" vacíos, antimensajeros, hombres incapaces de articular palabra. Este embotamiento es un estado que obliga al hombre a evadirse en la experiencia, en la diversión, en la actualidad, toda vez que éstas son las únicas formas disponibles en este momento que confieren algo así como un sentido. Para los desheredados y los embotados no hay ninguna misión, ninguna transmisión ningún mensaje que portar. El individuo es simplemente el hombre que carece de misión, el anti-mensajero, representa un producto defectuoso, esto es justo lo que quiere hacer la educación moderna del ser humano: productos defectuosos que a través de su trabajo personal, han logrado ser un producto finalmente utilizable, eso que casi nadie consigue completar.

1. 5 SLOTERDIJK, Peter, "Actio in distans, Sobre los modos de formación teleracional del mundo", Traducción del alemán de Marta Kovacsics M. para Revista NÓMADAS № $28-2008$, Instituto de Estudios Sociales Contemporáneos, Facultad de Ciencias Sociales, Humanidades y Arte -Universidad Central, Colombia: 'Ciberculturas: metáforas, prácticas sociales y colectivos en red' - http://biblioteca.clacso.edu.ar/ar/libros/colombia/iesco/nomadas/28/-. Originalmente pronunciada por Sloterdijk en 2007 en el Congreso Internacional "Ontología de la Distancia", Organizado por la Universidad Autónoma de Madrid, entre el 12 y 16 marzo 2007, Programa recogido y documentado por Revista Observaciones Filosóficas en la sección Documentos: $<$ http://www.observacionesfilosoficas.net/congresoontologia.html> 
Mientras los llamados "mass-media" roban masivamente a los seres humanos sus propiedades mediales, estos desarrollan los signos característicos del "último hombre" en el peor sentido de la expresión. Vivimos dentro de nosotros mismos la larga agonía del ángel. Los últimos hombres son "ángeles" vacíos, antimensajeros, hombres incapaces de articular palabra. Este embotamiento es un estado que obliga al hombre a evadirse en la experiencia, en la diversión, en la actualidad, toda vez que éstas son las únicas formas disponibles en este momento que confieren algo así como un sentido. Para los desheredados y los embotados no hay ninguna misión, ninguna transmisión ningún mensaje que portar. El individuo es simplemente el hombre que carece de misión, el anti-mensajero, representa un producto defectuoso, esto es justo lo que quiere hacer la educación moderna del ser humano: productos defectuosos que a través de su trabajo personal, han logrado ser un producto finalmente utilizable, eso que casi nadie consigue completar.

Sloterdijk desarrolla así una teoría de las comunicaciones a partir de un fresco histórico universal de formatos hegelianos, vale decir, como un gran relato que intenta dar cuenta de la unidad de la evolución nato-cultural de la especie humana. Sloterdijk, como se ve, no comienza su relato presuponiendo al hombre, sino aguardando el momento histórico de su nacimiento en el seno de las primitivas hordas. Como él mismo sentencia: "resulta esencial a la paleopolítica que no presuponga al hombre, sino que lo genere". ${ }^{6}$ El hombre, tal y como se conoce hoy, es una criatura tardía surgida en el estadio histórico de la política clásica en la era de los grandes imperios.

Sloterdijk intenta así situarnos en aquel tiempo original cuando el hombre salió de entre la niebla, antes de las primeras civilizaciones. Para Sloterdijk la obsesión por las culturas superiores es la mentira esencial y el error capital no sólo de la historia y de las humanidades, sino también de la ciencia política y de la psicología. Ella destruye, al menos como consecuencia última, la unidad de la evolución humana y la conciencia de la cadena de innumerables generaciones que han elaborado nuestros "potenciales" genéticos y culturales. El hombre no es -como pretende el interés ideológico de las altas culturas- una burgués animal de Estado, que necesita, para la plenitud de su esencia, capitales, bibliotecas, catedrales y embajadas, sino más bien un ser que se constituye a partir de su participación en un núcleo íntimo, en una ámbito de mutualidad. De modo que cuando superamos esta anulación de la prehistoria queda a la vista la constitución milenaria de la humanidad, a la que sólo hace poco la obra Lèvi Strauss7 ha contribuido a

6 SLOTERDIJK, Peter, En el mismo barco. Ensayo sobre la hiperpolítica. Ediciones Siruela, Madrid, 1994, p, 24.

$7 \quad$ Al distinguir entre tiempo e historia Lévi-Strauss llama la atención acerca de dos hechos. En primer lugar, que si bien toda sociedad humana vive en el tiempo, no toda sociedad ha elaborado su historia, en el sentido de que no toda sociedad ha elaborado interpretaciones conscientes de su temporalidad. Tal como lo entendemos nosotros, la historia se mueve en el plano de las interpretaciones conscientes de un discurrir lineal de la temporalidad. En este sentido, no puede considerarse como una producción intelectual universalizable. En segundo lugar, la distinción entre tiempo e historia permite ponemos en guardia ante una concepción etnocéntrica de la temporalidad. En su construcción social, el tiempo no tiene por qué ajustarse siempre a un esquema de sucesión lineal. Su célebre distinción entre un tiempo irreversible y acumulativo y un 
iluminar.

Las "sociedades primitivas" parecen pensadas para resistir el cambio y anular la acción del tiempo. Empeñadas en durar y no como la nuestra en cambiar, dirigen sus energías a replicar, en su organización social y en su cultura, las condiciones originarias

de

la

sociabilidad.

\section{2.- La tendencia a la repetición de lo arcaico en lo técnico; sistemas neuro- simpáticos armonizados en el horizonte de las telecomunicaciones masivas.}

De este modo si toda historia de los medios es estructuralmente la historia de las transferencias de pensamientos, entonces la aspiración última de todos los actos telecomunicativos debiera ser que un día pudiera ser posible acercarse nuevamente sin veladuras, directamente a los cerebros de los otros. Si existe de verdad la tendencia a la repetición de lo arcaico en lo técnico, ésta debería llegar a reproducir los antiguos diálogos locales de los sistemas neuro-simpáticos armonizados entre sí, en el horizonte de las telecomunicaciones y las comunicaciones masivas. Esto finalmente se muestra en la proliferación de los teléfonos móviles o celulares, que aportan a la reproducción de la oralidad arcaica en el nivel de la aldea global. Sin embargo, la mediología tecnológica no se detiene y alienta esperanzas escatológicas en torno a que al final de todos los días mediáticos, un comunicador debería ser capaz de irradiar sus propios pensamientos directamente en los cerebros de personas lejanas. Para esto sólo sería necesario un sistema neuro-telepático con una técnica avanzada de direcciones. Un sujeto-emisor solo necesitaría adaptar sus intenciones lógicas a un grupo de direcciones neurológicas, a quienes en la edad media mediática se les denominaba "personas", e inmediatamente se desarrollaría en un monitor interno del receptor, un proceso de recepción, al cual el destinatario sólo tendría que aportar lo suficiente para poner su sistema en recepción.

En la época final de los medios, los ojos y oídos tan exigidos hoy en día serían obviados mediante el proceso neuro-telepático del bypass ${ }^{8}$. Podríamos, con la ayuda de suaves tecnologías rompe cabezas, dirigirnos directamente a nuestra comunidad de nervios desde cualquier distancia, y de tal manera que ya no nos deberíamos dejar impresionar por las tan populares indicaciones respecto a la reserva de referencia propia de los neuro-sistemas. En aquellos días de los que ya

tiempo reversible y no acumulativo opera en esta línea. El primero sería el propio de sociedades como la nuestra que basan el progreso en la acumulación de las experiencias y el desarrollo de las ciencias y las técnicas. El segundo, el propio de las "sociedades primitivas" que estudian los etnólogos.

Las "sociedades primitivas" parecen pensadas para resistir el cambio y anular la acción del tiempo. Empeñadas en durar y no como la nuestra en cambiar, dirigen sus energías a replicar, en su organización social y en su cultura, las condiciones originarias de la sociabilidad.

8 SLOTERDIJK, Peter, Sloterdijk, "Actio in Distans; Sobre los modos de formación teleracional del mundo". En Nómadas No 28 . IESCO, Instituto de Sociales Contemporáneos, UC, Universidad Central, Bogota Colombia. Abril, 2008. 
sólo nos separa un siglo de investigaciones y desarrollo, podríamos provocar técnicamente y mediático-masivamente, lo que hoy los psicóticos de la influencia y algunos telecomunicadores ya dan por hecho: nos podríamos transponer sin encontrarnos físicamente, en estados maravillosos o terribles de discretas obsesiones telecomunicativas; nos sumergiríamos mediante circuitos intercerebrales a través de grandes distancias y no solamente enviaríamos y recibiríamos, a diferencia del platonismo, imágenes originarias o ideas eternas, sino también representaciones individualizadas y mensajes con fecha, dirección y localización.

Los que hoy en día llamamos "nuevos medios" son entonces en su totalidad tecnologías pesadas, externas y caducas, si uno sacude la cabeza sobre la superflua y malintencionada intermediación que trató de monopolizar y explotar comercialmente la transferencia de pensamientos entre los hombres. El único problema que debería ser resuelto es la protección de la esfera cerebral privada. Probablemente, las personas que no quieran estar en recepción, tendrán que portar cascos de protección, es decir, cascos anti-neuro-telepatía, disponibles si se busca desconectarse de los siempre presentes conciertos de transferencia. La palabra intelectual irritante de aquella época será neuro-globalización. La forma hoy en día más extendida del rechazo a la información, el no-entender, sería derogada en la era final de la transferencia de pensamientos ${ }^{9}$. Así, se deberá ejecutar explícitamente cada acto de la negación del entendimiento y llevarlo a cabo según las reglas del arte. Ante semejantes perspectivas del futuro, deberíamos gozar de nuestras reservas naturales del no-entender, mientras haya tiempo.

\section{3.- Fascinación del ser humano por el ser humano; facialidad y proceso mismo de antropogénesis}

Como se ha señalado, entre los seres humanos, en la esfera de proximidad familiar funciona un juego incesante de contagios afectivos10 que concurren simbiótica, erótica y miméticamente. Los seres humanos viven sintonizados en un círculo de proximidad, el de la fascinación del ser humano por el ser humano11.

La fascinación de proximidad se da en el espacio humano en el ámbito de cercanía propio de la posibilidad de facialidad y va unida al proceso mismo de antropogénesis $^{12}$. Todo lo específico y singular que se anota en el rostro como

9 SLOTERDIJK, Peter, Sloterdijk, "Actio in Distans; Sobre los modos de formación teleracional del mundo". En Nómadas No 28 . IESCO, Instituto de Sociales Contemporáneos, UC, Universidad Central, Bogotá: Colombia. Abril, 2008.

10 SLOTERDIJK, Peter, Esferas II, Globos, Macroesferología, Cap. 3, Ediciones Siruela, Madrid, 2004

11 SLOTERDIJK, Peter, Esferas II, Globos, Macroesferología, Ediciones Siruela, Madrid, 2004, Cap. 3, p. 197.

12 SLOTERDIJK, Peter, Esferas I, Cap. 2: "Entre rostros. Sobre la emergencia de la esfera 
rasgo de carácter o como patrón y línea de temperamentos regionales y propiedades adquiridas sólo puede entrar en el rótulo facial a través de la protracción $^{13}$ del tierno entretenimiento del mutuo iluminarse de los rostros de madres e hijos en el período del bonding posnatal. Su hacia aquí y hacia allá está anclado en antiguas sincronizaciones histórico-tribales de los juegos de ternura protoescénicos; es parte de un conjunto de esquemas innatos de participación bipersonal emotiva.14

El darse cuenta de que los seres humanos existimos como tales en el entrecruzamiento de muchas conversaciones en muchos dominios operacionales distintos que configuran muchos dominios de realidades diferentes ${ }^{15}$, es particularmente significativo porque nos permite recuperar lo emocional como un ámbito fundamental de lo humano. ${ }^{16}$

Las emociones se viven como dominios de conductas relacionales y constituyen el fundamento de todo nuestro de todo nuestro quehacer. No sólo eso. Todo razonar ocurre como un constructo coherente a partir de ciertas premisas o puntos de partida que se aceptan a priori desde la emoción que se vive en el instante de razonar. Esto es, las emociones no constituyen interferencias con nuestro ser racional, sino que le dan a nuestro razonar sentido y significado relacional. Pero como fenómenos de nuestro ser biológico, nuestro emocionar surge en nuestro fluir fisiológico en la relación, y se puede evocar desde la modulación de la corporalidad, particularmente desde la modulación de los ritmos respiratorios. Tal evocación permite darse cuenta del propio emocionar, e inspirar, en el espectador, cierta emoción, como ocurre en la representación teatral ${ }^{17}$.

Ahora bien para realizar un examen de estas primigenias sincronizaciones humanas es necesario considerar las anomalías que comienzan con -lo que Sloterdijk denomina- las arcaicas "culturas de la vergüenza", en las que a cada uno le habría gustado volver invisible su interior, porque sufrían bajo la exposición extrema de sus afectos ante la sensibilidad de los demás. El poderoso afecto de la vergüenza es en sí mismo sólo un sedimento evolutivo de la imposibilidad de ocultar el interior ante la sensibilidad de los otros. Los pensamientos privados aparecen desde el punto de vista paleo-psicológico como un absurdo completo. La idea de que existe un interior protegido en el cual el individuo puede recluirse, flexionandose sobre sí mismo, no aparece antes del primer giro individualista propio de la Antigüedad. Sus publicistas fueron los filósofos o si, se quiere, los

íntima interfacial", Editorial Siruela, Madrid, 2003, 156.

13 Protracción: Movimiento de una parte del cuerpo hacia adelante, en un plano transversal; como cuando movemos la cabeza (o específicamente la quijada hacia adelante).

14 BILZ, Rudolf, "Sobre la participación emocional. Una contribución al problema del ser humano en su entorno", En R. B., Die unbewältigte Vergangenheit des Menschengeschlechts. Beiträge zu einer Paläoanthropologie, Frankfurt 1967, pp. 39 - 73.

15 Este punto es epistemológicamente relevante para evidenciar -desde una matriz biológicacultural disidente-.

16 MATURANA, Humberto, Desde la Psicología a la Psicología, Cap. "Lenguaje y realidad; el origen de lo humano", Editorial Universitaria, Santiago, 2008. p. 100

17 BLOCH A., Susana y MATURANA, Humberto, "Sobre el emocionar y su evocación desde el respirar", Fragmento. 
sofistas, antecesores de los intelectuales modernos. Ellos, los inventores del apartheid psicológico de lo individual, dieron forma a la idea revolucionaria, pero errónea, de que el pensamiento verdadero sólo es posible como un pensar propio y distinto-al-tonto-pensar-de-las-multitudes. De sus impulsos se deduce el efectivo y amplio modelo-de-la-clausura-en-la-cabeza, cuya perspicacia política se conoce: los pensamientos son libres, nadie los puede adivinar. Esta fórmula del liberalismo del siglo XIX significa, en consecuencia, que tan sólo los pensadores de pensamientos nuevos e inesperados son invisibles para los celadores de los pensamientos convencionales.

Tenemos pues que el ocultamiento de pensamientos surge en las sociedades diferenciadas, otras personas tienen en efecto otros pensamientos en la cabeza. lo que yo mismo no pienso y nunca he pensado no puedo adivinarlo en los demás.

Y por eso mismo, en esta clase de sistemas se infla la telecomunicación: ésta expresa el nuevo contenido, en el sentido de que la transferencia de pensamientos entre extraños ya no es posible en la forma de la empatía participativa, sino mediante comunicaciones explícitas que superan las distancias y por las que los participantes pagan altos precios a partir del uso de los sistemas de símbolos sólo hay que pensar en los enormes costos de la alfabetización inicial-, costos que hoy en día todos tratan de reprimir, porque ya han sido socializados. (Si el alfabeto fuera tan caro como una red telefónica, se ahorraría decididamente en las palabras escritas). En sociedades diferenciadas, con distintos trabajos y pensamientos, son los psicoterapeutas los encargados del entretenimiento y los proveedores de redes los que se deben ocupar de que los individuos no caigan demasiado profundo en la privacidad patológica de sus pensamientos y sentimientos.

Los hombres, todos ellos, son mensajeros potenciales, informantes de un estado de cosas, por mucho que esta observación sea mal vista por la teoría dominante de los medios, por la ciencia ilustrada, que ensalza obsesivamente las imágenes y los aparatos.

Pese a todo Sloterdijk sostiene que "el psicoanálisis sigue siendo la praxis de cercanía personal más interesante en el mundo moderno"18 lo que podría levantar los estados de ánimo del a menudo vilipendiado cuerpo teórico del psicoanálisis, a lo largo del texto -sin embargo- no cesa de mostrar su desacuerdo con los conceptos del psicoanálisis lacaniano, mientras que frente al joven Freud manifiesta profunda admiración, como en su momento la tuvieron otros genios de la crítica epistemológica -como Wittgenstein19 (cuya Filosofía del lenguaje Teoría de los juegos de lenguaje y formas de vida- examinaremos luego en profundidad) quien se mostraba crítico con Freud, pero también ponía de relieve

18 SLOTERDIJK, Peter, Esferas I, Ediciones Siruela, Madrid, 2003, p. 277

19 Wittgenstein admiraba a Freud por las observaciones y sugerencias de sus escritos, por «tener algo que decir» incluso allí donde, según su opinión, estaba equivocado. Por otro lado, pensaba que la enorme influencia del psicoanálisis en Europa y América era perjudicial, «aunque pasaría mucho tiempo antes de liberarnos de nuestra sumisión a él». Para aprender de Freud hay que ser crítico, y el psicoanálisis por lo general lo impide. 
cuánto interés encierra, por ejemplo, lo que Freud dice sobre la noción de "simbolismo onírico" o su sugerencia de que al soñar estoy "diciendo algo" en algún sentido. Intentaba separar en Freud lo valioso y el "modo de pensar" que quería combatir.

\section{2.- Los cerebros como medios primordiales20. Discretas obsesiones telecomunicativas y neurología}

El individualismo cerebral ignoraría que un cerebro sólo se constituye en su ejercicio, es decir en juego conjunto con un segundo, y más allá de ello con un conjunto mayor de cerebros, es ello lo que despierta a cierta capacidad funcional, operativa. Los cerebros son medios de lo que otros cerebros hacen y han hecho. Un cerebro es en actividad con otras inteligencias, de modo que no es sujeto, sino medio y círculo de resonancias. A diferencia de la inteligencia alfabética, capaz de distancia, la inteligencia prealfabética está remitida a un denso clima de participación; inmersa en comunicaciones de proximidad, necesita para su despliegue la experiencia de una mutualidad y comunión actual de cerebros y nervios. En la era de la lectura éste -el cerebro- se convertirá en la república cuasi telepática de los sabios, que no en vano tiene sus espíritus del tiempo: gracias a la escritura, además, pueden volver los espíritus del pasado a la consideración actual. La escritura es, asimismo, la que hace posible que haya individuos que se retiren de la sociedad para complementarse a sí mismos con la palabra de autores lejanos en el tiempo y en el espacio: de modo que quien sabe leer, sabe también estar sólo21. Sólo la alfabetización hace posible que haya individuos que se retiran de la sociedad para complementarse a sí mismos con la palabra de autores de letra presente: quien sabe leer, sabe también estar sólo. Sólo la alfabetización hace posible la anacoresis; el libro y el desierto van unidos. Pero tampoco en la

20 Este apartado es una versión ampliada del Artículo [VÁSQUEZ ROCCA, Adolfo] "Sloterdijk: Modelos de comunicación oculto-arcaicos y moderno-ilustrados. Para una época de ángeles vacíos", En NÓMADAS, Revista Crítica de Ciencias Sociales y Jurídicas - Universidad Complutense de Madrid, NÓMADAS. 26 | Enero-Junio.2010 (II), pp. 229-249. http://www.ucm.es/info/nomadas/26/avrocca.pdf

21 La relación de uno a uno consigo mismo, el pensamiento como diálogo interior, como caja de resonancia "el hombre interior no existe antes de que los libros, las celdas de los conventos, los desiertos y las soledades lo definan; la razón, con su voz amortiguada, no puede habitar en el hombre antes de que él mismo se haya convertido en celda o cámara silente. Un yo razonable no llega siquiera a existir sin aislamiento acústico. La lectura como comunicación a distancia esta ligada a la posibilidad de distanciarse. Una cultura que permite a las personas retirarse del ruido de los grupos compensa a sus representantes con el acceso clarividente a lo ocurre en sus propias mentes así como en la de otros que -también suspendidos en el tiempo de la lecto-ecritura están fluyendo en esa misma corriente vital que es el espacio creativo (espacio en que el mundo queda fuera -cuando el transcurrir mundano lleno de ocupaciones y litigios se congela, cuando desaparece el apremio de lo domestico y se repara la avería de lo cotidiano); de modo que todos los que escribieron y leen lo hacen en este mismo espacio y en este mismo tiempo sustraído, así y sólo así puede fundarse una tele-comunicación, sólo bajo la condición de ser contemporáneos, contemporáneos a Homero, a Sófocles, a Virgilio, a Dante, a Kafka, 
clausura solitaria hay pensamientos propios en última instancia. Precisamente por el retiro al espacio socialmente vacío triunfó por encima de toda la idea de Dios como primer lector del pensamiento; al retirarme al desierto obligo a Dios a que me haga caso. Precisamente al Dios de los eremitas pasaron restos de la íntima función de participación que se daba en los grupos de otros tiempos. Él garantizaba que el asceta en el desierto no estuviera sin su gran segundo, que le protege, observa, escucha, penetra con la mirada.

La escritura fue la primera que explosionó los círculos mágicos de la oralidad y emancipó a los lectores del totalitarismo de la palabra actual, hablada en un ámbito de cercanía; escritura y lectura, sobre todo en su modalidad griega, democrática, autodidacta de uso, llevaron a ejercitarse en la no-conmoción. La era oral significó, ciertamente, lo mismo que el pasado mágico-manipulativo del alma, dado que en ella la posesión actual por las voces y las sugestiones y las sugestiones de los miembros de la tribu significaba el caso normal. La posesión por lo normal, lo medio, lo actual no es algo que aparezca naturalmente como tal: en las familias, pueblos y vecindades, se le considera hasta hoy como el tipo obvio de comunicación. Ahí se encubre el hecho de que en el mundo oral todos los seres humanos son magos que se colocan recíprocamente en una vía más o menos poderosa de normalización (de la que sólo se emancipa uno de los comagos, por ejemplo por viajes o conversaciones con extraños).

\section{3.- La Idea freudiana de transferencia, mesmerismo y psicoanálisis}

Entre los seres humanos, en la esfera de proximidad familiar, como hemos señalado, funciona un juego incesante de contagios afectivos ${ }^{22}$. Son este tipo de inspiraciones mutuas el fundamento de la asociación de seres humanos, asociaciones que van de la burbuja mínima de gemelos a las comunas y pueblos. El espacio interpersonal está saturado de energías que, concurriendo simbiótica, erótica y miméticamente, generan esta corriente de contagios afectivos, desmintiendo con ello la ilusión de la autonomía del sujeto ${ }^{23}$. Para Sloterdijk el individuo, en el sentido usual de las sociedades modernas, es una creación tardía de las "altas" culturas. Mientras los lazos afectivos son muy estrechos, la vida de cada uno trascurre amparada por el ruido constante del grupo. Nadie se aparta de este clima envolvente, prueba audible de la unión de todos por la sangre y los parentescos. En el paisaje nativo, cada tribu declara su identidad mediante su característica producción sonora. Estar siempre al alcance de la voz es mantenerse en la seguridad de lo familiar y propio $^{24}$. Así los seres humanos viven

22 SLOTERDIJK, Peter, Esferas II, Globos, Macroesferología, Cap. 3, Ediciones Siruela, Madrid, 2004

23 SLOTERDIJK, Peter, Sloterdijk, "Actio in Distans; Sobre los modos de formación teleracional del mundo". En Nómadas No 28. IESCO, Instituto de Sociales Contemporáneos, UC, Universidad Central, Bogota: Colombia. Abril, 2008.

24 El surgimiento del individuo en las sociedades posteriores exige -según Sloterdijk- que en 
sintonizados en un círculo de proximidad donde la ley fundamental de la intersubjetividad, tal como se concibió en la época premoderna, es la de la fascinación del ser humano por el ser humano ${ }^{25}$. En estos grupos pequeños, que viven bajo la ley de la mutualidad, el quehacer del uno es el quehacer del otro; también los pensamientos de unos son generalmente los pensamientos del otro.

Durante la mayor parte del estadio antropológico primitivo casi la totalidad de lo que cada persona pensaba y sentía era en tal grado transparente para su entorno, que se asumía como si fueran vivencias propias. La imaginación de las representaciones privadas (que deberían ser transmitidas mediante formulaciones explícitas) no tenía apoyo en la experiencia o en el concepto espacial social: aún no había para cada uno celdas o apartamentos, ni en las arquitecturas imaginarias, ni en las arquitecturas físicas de la comunidad.

En un mundo así de permeable, la accesibilidad de los otros en situaciones estándar no suscita problemas. Telecomunicadores y mediamáticos literalmente no tendrían nada que hacer, porque las antiguas hordas humanas eran en sí mismas asociaciones mediamáticas puras. Los hombres funcionan como medios primarios. Los aparatos ${ }^{26}$, en un primer momento, no hacen más que añadirse como amplificadores a estas cualidades mediales humanas. Muchos de los hombres que pierden y olvidan sus propiedades mediadoras para convertirse en sombríos consumidores parasitarios de bienes e informaciones ${ }^{27}$. En estas transmisiones se cifra todo el proceso de humanización.

Nos hemos referido a la praxis de cercanía personal como una característica propia de los seres humanos, entre los cuáles se da una fascinación

un determinado momento hayan aparecido, novedosas prácticas de silencio. Pero ¿cómo comienzan tales prácticas en las culturas más avanzadas? No fue sino con la escritura y el consiguiente ejercicio de la lectura silenciosa que se produjo este momento decisivo. La individualidad capaz de reconocerse a sí misma presupone así que los miembros del grupo puedan retirarse a ciertas islas de tranquilidad en las que les llama la atención una posible diferencia entre las voces de lo colectivo y las voces interiores, una de las cuales se destaca, finalmente, como la propia. Otras cualidades inseparables de la individualidad también están ligadas a la posibilidad de distanciarse y de acceder al sosiego y al silencio. Una cultura que permite a las personas retirarse del ruido de los grupos compensa a sus representantes con el acceso a lo que pudiera ocurrir en sus propias cabezas; les regala unas vacaciones de los prejuicios y de esas gesticulaciones que no redundan sino en que la intimidad sea tan ruidosa e inquieta como la exterioridad compartida con otros. ¿Qué es una convicción firme sino una fuerte voz interior que se ha adquirido ejercitándose? Esta gritería de las opiniones en mí es sofocada mediante la meditación filosófica. Un servicio considerable entre los que presta el silencio, según Sloterdijk, es la separación de lo público y lo privado. Estos dos conceptos, tan importantes en política, reflejan la diferencia entre los modestos ruidos familiares y la algarabía en los grupos. Lo que después se llamará política no es al comienzo más que una forma cultural del hábito de hablar a gritos.

25 SLOTERDIJK, Peter, Esferas II, Globos, Macroesferología, Ediciones Siruela, Madrid, 2004, Cap. 3, p. 197.

26 Ésta es la razón por la cual todos los hombres son mensajeros potenciales, informantes del estado de las cosas, por mucho que este tipo de cosas sea mal visto por la teoría dominante de los medios, que ensalza obsesivamente las imágenes y los aparatos. Por desgracia, los únicos que siguen aplicando el concepto de "médium" al ser humano son los ocultistas, lo cual, si se mira bien, no deja de ser un fenómeno escandaloso desde el punto de vista teórico1. Siempre que se habla de medios, se hace referencia a aparatos y programas.

27 SLOTERDIJK, Peter, Experimentos con uno mismo, Pre-Textos, Valencia, 2003, p. 53. 
experimentada en el círculo mágico de la proximidad, se trata de agitados vínculos afectivos y de un permanente concierto de transferencias. Así, los seres humanos mutuamente seducidos componen un campo de vinculaciones convirtiéndose ellos mismos en operadores de múltiples influjos creadores de espacios y conformadores de esferas.

\section{4.- Seres humanos en el círculo mágico}

Entre los humanos la fascinación es la regla, y el desencanto, la excepción28. Como criaturas que desean e imitan, los seres humanos experimentan el anhelo del otro. En el lenguaje de la tradición figura esto como ley de la simpatía; ésta estipula que el amor no puede hacer otra cosa que despertar amor; del mismo modo, el odio genera su respuesta congénere; la rivalidad infecta a los interesados en el mismo objeto con la vibrante ambición del competidor.

Sloterdijk sostiene que es la simpatía, la participación en un círculo mágico de atracciones, de fascinación es lo que caracteriza nuestro espacio existencial más real; el aire en el que "vivimos, nos entretejemos y somos", como San Pablo dice en su discurso a los areopagitas. Cuando entramos en nosotros mismos, percibimos en nuestro interior una dimensión que al mismo tiempo está en torno a nosotros. En mí está lo que yo respiro, lo que yo comparto, aquello de lo que soy parte y contrapartida. Las esferas son espacios de simpatía, espacios de afinación, espacios de participación. Si no presuponemos su existencia, no podríamos compartir palabra alguna con el otro, y tan pronto las damos por presupuestas, también las dotamos de una nueva intensidad. Hasta la interacción más banal implica nuestra participación en la constitución de esferas. Sin ellas no habría familias, comunidades existenciales, comunas, equipos, pueblos. Nadie soportaría pasar un solo día en la misma habitación con otro hombre si los dos participantes no tuvieran la extraña capacidad de conectar en medio de frecuencias comunes, de sintonizarnos29.

"Hay que insistir en que la transferencia es la fuente formal de los procesos creadores que dan alas al éxodo de los seres humanos a lo abierto. No transferimos tanto afectos exaltados a personas extrañas como tempranas experiencias espaciales a lugares nuevos, y movimientos primarios a escenarios lejanos. Los límites de mi capacidad de transferencia son los límites de mi mundo"30

\section{5.- Actio in Distans; ciudadanía mundial electrónica.}

28 SLOTERDIJK, Peter, Esferas I. Burbujas, Ediciones Siruela, Madrid, 2003. / Cap. 3. Seres humanos en el círculo mágico--Para una historia de ideas de la fascinación de la proximidad. p. 197

29 SLOTERDIJK, Peter, Experimentos con uno mismo. Conversaciones con Carlos Oliveira. Trad. Germán Cano. Editorial Pre-textos. Valencia, 2003, p. 93.

30 SLOTERDIJK, Peter, Esferas I. Burbujas, Ediciones Siruela, Madrid, 2003., p. 23-4. 
Así, según Sloterdijk, toda la historia de los medios no es sino una historia de la "transferencia del pensamiento" donde el medio fundamental es el cerebro humano. Al comienzo el hombre estaba en un estado de 'transparencia' hacia el otro, pero cuando aparece la propiedad privada cambia el modo de actuar y surgen las "culturas de la vergüenza", donde ya no es algo transparente y volvemos los intereses a nuestro propio beneficio, aquí necesitamos de medios de comunicación porque hemos cambiado de paradigma.

Necesitamos de las palabras y de mediadores de éstas, porque ya hemos ocultado nuestra transparencia y encubrimos nuestras experiencias y sentimientos por pudor o vergüenza. Desde ese momento se establece el lenguaje y pasan a ser culturas de la "vergüenza", dejan de ser culturas de la "mutualidad".

En este punto podemos retomar nuestras reflexiones iniciales, para alcanzar el horizonte del problema actual. A comienzos de la época de la modernidad tecnológica se impuso el entendimiento de que las transferencias de pensamientos, que se dan en nuestra estructura mundial, no pueden producirse ni en la comunión arcaica de los cerebros en el tráfico (interior) telepático-sensitivo, ni en los sutiles y anamnésicos diálogos a distancia de las almas individuales inteligentes con el dios de los filósofos. Lo que ahora cuenta es una transferencia de pensamientos des-regulada de cierta manera, y mixta, en dirección horizontal y vertical, a través de medios simultáneamente comunicativos e informativos. Entre ellos, primero sobresale el libro, al cual le ha salido una competencia muy efectiva desde el siglo XIX, mediante los sistemas eléctricos y electrónicos. En este proceso, la verticalidad es desplazada cada vez más por la horizontalidad, hasta que se llega a un punto desde el cual los participantes comprenden en los juegos de sociedad que son comunicativos e informativos, que ya nada les llega desde arriba y que están, con sus cerebros, sus medios, sus equivocaciones y sus ilusiones, solos en este mundo decantado. Están condenados a una ciudadanía mundial electrónica, cuyas categorías son dadas mediante los hechos de la densificación del mundo y de la tele-vecindad de todos con todos. Lo que de hecho se define con la palabra telecomunicación, implica una forma de mundo tele-operativa, que es a su vez definida por actiones in distans de toda naturaleza. A ella le corresponde una conciencia que debe convencerse cada vez más de sus tareas tele-morales.

\section{6.- La civilización altamente tecnológica, el Estado del bienestar, el mercado mundial, la esfera de los media.}

La civilización altamente tecnológica, el Estado del bienestar, el mercado mundial, la esfera de los media: todos esos grandes proyectos quieren imitar en una época descascarada la antigua seguridad de las esferas, pero esta se ha vuelto imposible. Ahora el ser humano tiene que procurarse redes y pólizas de seguros que han de ocupar el lugar de los caparazones celestes; la telecomunicación debe 
imitar a lo envolvente. El cuerpo de la humanidad quiere procurarse un nuevo estado de inmunidad dentro de una piel electrónico-mediática.

La teoría de las esferas es un instrumento morfológico que permite reconstruir el éxodo del ser humano de la simbiosis primitiva al tráfico histórico-universal en imperios y sistemas globales como una historia casi coherente de extraversiones; ella reconstruye el fenómeno de la gran cultura como la novela de la transferencia de esferas desde el mínimo íntimo, el de la burbuja dual, hasta el máximo imperial, que había que representar como cosmos monádico redondo. Si la exclusividad de la burbuja es un motivo lírico, el de la inclusividad del globo es uno épico.

Los hombres se blindan contra los horrores de un espacio sin límite, ampliado hasta el infinito, mediante la construcción, pragmática y utópica al mismo tiempo, de un invernadero universal que les garantice un habitáculo para la nueva forma moderna de vida al descubierto. El ser humano descascarado desarrolla su psicosis epocal respondiendo al enfriamiento exterior con el desarrollo de curiosas políticas de climatización.31

El destino de todos los sistemas metafísicos de inmunidad se decide frente a la cuestión de si los seres abiertos al gran mundo, los seres humanos de la época de imperios y ciudades, consiguen dar plenamente el salto del autocobijo colectivo en comunidades ciudadanas fortificadas al autoaseguramiento individual, más allá de patrias ocasionales. ¿Cuánta nostalgia y cuánta pérdida es capaz de soportar el ser humano? ¿Cuánto desacostumbramiento de los primeros lugares necesita el alma capaz de pensar para recogerse en sí misma? ¿Cuanto desarraigo es necesario para hacerse sabio, es decir, resistente al destino? ${ }^{32}$

¿Cómo, pues, pueden crecer las esferas? ¿De qué modo aprenden pequeños pueblos, hordas, familias, parejas, mundos íntimos a sobreponerse a las catástrofes, a sus escisiones, a las amenazas de ser avasallados por fuerzas explosivas tanto internas como externas? ¿Cómo es posible que no todos los grupos desafiados y vencidos se desvanezcan en silencio en lo no-histórico, y que algunos de ellos saquen fuerzas de flaqueza para asimilar lo que normalmente sólo produce destrucción? ¿Qué clase de cambio en su modo de vida llevan a cabo las pequeñas comunidades humanas cuando consiguen soportar lo insoportable más allá de la medida normal? ¿Qué sucede con los unidos cuando consiguen imponer su supervivencia frente a pérdidas insustituibles? ¿Cómo aprenden a concentrarse así en sí mismos, a superarse, a endurecerse así, a comprometerse de tal modo con una visión de sí mismos que son ellos mismos los que se convierten, más bien, en fuerzas del destino para otros, en lugar de soportar el destino condicionados por circunstancias externas?33

Cualesquiera que sean las respuestas a estas preguntas, han de tener

31 VÁSQUEZ ROCCA, Adolfo, Peter Sloterdijk; Esferas, helada cósmica y políticas de climatización, Colección Novatores, No 28, Editorial de la Institución Alfons el Magnànim (IAM), Valencia, España, 2008

32 SLOTERDIJK, Peter, Esferas II, Globos, Ediciones, Siruela, Madrid, 2004, p 309.

33 SLOTERDIJK, Peter, Esferas I, Burbujas, Ediciones, Siruela, Madrid, 2003, p 147. 
inevitablemente una implicación morfológica y un sentido inmunológico y esferológico mediado por ella. De lo que se trata en cada caso es de aclarar cómo los grupos humanos soportan sus crisis de forma con relación a fuerzas exteriores y tensiones internas34.

Como respuesta a estos trastornos de los sistemas políticos-existenciales de inmunidad, para cerrar brechas en los amurallamientos psíquicos [fortificaciones] y derrumbes en las cubiertas de la vida [asoladas] es que tanto profetas [fundadores de religiones], sacerdotes, y, por cierto, filósofos, desarrollan los procedimientos de curación [el arte médica]. "Así, también, las llamadas "imágenes de mundo" [cosmovisiones] de las grandes culturas surgieron de reparaciones agresivas hechas a las más antiguas concepciones mítico-animistas. De modo tal que por sus rasgos fundamentalmente espirituales, todas ellas representan ontologías terapéuticas, dado que en último término no tratan de la cuestión -cómo los individuos expuestos al peligro en las comunidades no compactas del gran mundo [desconcertado y desconcertante], puedan todavía sentirse cobijados, en un receptáculo conformador de orden máximo- sino más bien de lo que se trata, en suma, en los grandes proyectos cosmológicos-sociales de las culturas antiguas, desde China hasta Grecia, es de la cuestión antropológico-terapéutica de cómo en las épocas turbulentas de la ciudad y el imperio los inquietos individuos aislados habían de arreglárselas para dar paso de la cosa pública humana falible a la ciudadanía imperecedera del universo.

Un grupo que hubiera atraído hacia su interior toda desmesura esencial, y en cierto sentido la hubiera superado o cercado, habría crecido hasta convertirse en un imperio o en una macroesfera altamente cultural. Por eso, sólo puede hablarse de una forma auténticamente macroesférica cuando también lo grande y lo máximo manifiestan carácter de mundo interior. En una gran esfera que se asemeje a un mundo interior la voluntad de poder ha de ser coextensiva con una voluntad de animación del espacio total36.

Fue un logro de las grandes culturas haber elevado la asimilación interior del exterior estresante a un nivel históricamente mantenible a largo plazo. Potencias mundiales que lograron ser algo más que improvisaciones militares fueron aquellas que consiguieron domesticar los monstruos inmensos de la exterioridad la muerte, el mal, la peste, lo extraño, lo desmedido- y traspasar a las generaciones siguientes, como hábito cultural, sus éxitos en esa domesticación. Aunque ninguno de esos monstruos pierde nunca del todo su pavorosa capacidad de intranquilizar, en las grandes cosmovisiones se los convierte, sin embargo, en

34 Las microesferas crecen hasta convertirse en macroesferas, en la medida en que consiguen incorporar las fuerzas exteriores estresantes en su propio radio. Se podría describir, por tanto, el crecimiento de las esferas como un derrotero de estrés en cuyo transcurso se llega a neutralizar lo exterior asimilándolo al interior esférico.

35 VÁSQUEZ ROCCA, Adolfo, "Peter Sloterdijk: Espacio tanatológico, duelo esférico y disposición melancólica" En NÓMADAS, Revista Crítica de Ciencias Sociales y Jurídicas ISSN 1578-6730 - Universidad Complutense de Madrid, | No 17 | Enero-Junio 2008 - - $^{\circ}$ | <http://www.ucm.es/info/nomadas/17/avrocca_sloterdijk2.pdf>

36 SLOTERDIJK, Peter, Esferas I, Burbujas, Ediciones, Siruela, Madrid, 2003, p. 148. 
estresores internos y se los pone dialécticamente al servicio del todo37. Las grandes culturas saben convertir en negatividades provechosas la exterioridad destructora. Utilizan lo monstruoso como hormonas de crecimiento para elevarse de formas microesféricas a macroesferas. El modelo de semejante dinámica de maduración se encuentra en el plano somático: "las llamadas enfermedades infantiles pueden describirse como un currículum de crisis corporales que permiten que en entornos específicos los sistemas inmunológicos se fortalezcan en el entrenamiento con sus invasores microbianos" ${ }^{38}$.

Como agente inmobiliario de una nueva ontología, Sloterdijk hace publicidad entre sus conciudadanos para que participen en dar el paso de residir en el ser. Vacunar la vida con la locura que se llama ser: gracias a esa operación el filósofo se arroga el derecho de presentarse en adelante como médico y auxiliar de mudanza de la vida cercada ${ }^{39}$-la filosofía se habrá convertido así en un equipo de socorristasbajo la marca de un experto en otros lugares y en otro modo de residencia, en general, el filósofo se ofrece a la sociedad enajenada como médico especialista en enfermedades de cultura, sentido y lugar.

Cuando uno se ha hecho un concepto de la globalización terrestre como acontecimiento fundamental de la época moderna puede comprenderse por qué en este momento una tercera globalización desencadenada por las rápidas imágenes de las redes conduce a una crisis general del espacio, que se designa por el concepto, tan habitual como oscuro, de virtualidad.

En sus investigaciones sobre la metafísica de la telecomunicación en grandes cuerpos sociales Sloterdijk da cuenta de cómo las iglesias y los imperios clásicos consiguen presentarse como globos solares, cuyos rayos parten de un centro monárquico, para iluminar la periferia de lo existente. Aquí se muestra por qué los intentos de la metafísica clásica de concebir lo existente, o lo ente en su totalidad, como una monosfera organizada concéntricamente han de fracasar no sólo por fallos inmanentes de construcción, sino porque una superesfera así, a causa de su forzada abstracción, representaba también una construcción inmunológica fallida. Debe recordarse que, si bien, la teoría de las esferas comienza como psicología de la formación interior de espacio a partir de correlaciones dúplice-únicas, pero se desarrolla necesariamente hasta convertirse en una teoría general de los receptáculos autógenos. Ésta suministra la forma abstracta de todas las inmunologías ${ }^{40}$.

37 SLOTERDIJK, Peter, Esferas I, Burbujas, Ediciones Siruela, Madrid, 2003, p. 149

38 SLOTERDIJK, Peter, Sin Salvación; Tras las huellas de Heidegger (2001), cap. VII: "La humillación por las máquinas (Sobre la significación de la novísima tecnología médica para la época)", Ediciones Akal, Madrid, 2011, p. 222.

39 VÁSQUEZ ROCCA, Adolfo, "Peter Sloterdijk: Espacio tanatológico, duelo esférico y disposición melancólica" En NÓMADAS, Revista Crítica de Ciencias Sociales y Jurídicas ISSN 1578-6730 - Universidad Complutense de Madrid, | No 17 | Enero-Junio $2008-1^{\circ}$ | <http://www.ucm.es/info/nomadas/17/avrocca_sloterdijk2.pdf>

40 SLOTERDIJK, Peter, "Un pensamiento punzante", En SOCIEDAD, Revista de la Facultad de Ciencias sociales, Universidad de Buenos Aires, № 26. , p. 147 y siguientes. 


\section{7.- Prácticas Antropotécnicas e implicación morfológica de los sistemas de inmunidad.}

En el tercer volumen de Esferas ${ }^{41}$ Sloterdijk se ocupa de la catástrofe moderna del mundo redondo. Con expresiones morfológicas describe la aparición de una era en la que la forma del todo ya no puede representarse con miradas imperiales en derredor desde un punto céntrico y panópticos circulares. Desde el punto de vista morfológico aparece la Modernidad, ante todo, como un proceso revolucionario formal. No en vano fue presentada por sus críticos conservadores como pérdida del centro y como insurrección contra el círculo de Dios; y así hasta hoy. Para viejos europeos católicos la esencia de la era moderna puede definirse aún por un único concepto: profanación de esferas. Nuestro planteamiento esferológico, mucho menos nostálgico, y sí intempestivo por caminos no católicos, depara los medios para caracterizar las catástrofes de la forma del mundo de la Modernidad la globalización terrestre y la virtual-, con expresiones sobre formaciones descentradas, no redondas, de esferas.

En "Espumas" Sloterdijk sostiene que las innumerables esferas humanas se aglomeran hasta formar paquetes de "espuma" que permiten pensar esa multitud de espacios humanos cerrados. Y es que al parecer no podía quedarse en el nivel de las burbujas protectoras del núcleo familiar o de la pequeña horda. Como se ha indicado, Sloterdijk interpreta la metafísica clásica como un sistema inmunitario simbólico que construía un película trascendente e indestructible en torno del ser humano. Mientras los mortales vivían bajo ese cielo, era plausible pensar que el cosmos era la casa de Dios -esa Esfera donde el centro está en todas partes y la circunferencia en ningún sitio- y los hombres, los inquilinos. En "Espumas" Sloterdijk demuestra por qué -a su juicio- esa monoesfera metafísica estaba destinada al fracaso.

Esto en razón de una contradicción que refleja el dilema formal de la situación actual del mundo: a través de los mercados y los medios de comunicación globales asistimos a una guerra sin cuartel entre modos de vida y entre mercancías de la información. Allí donde todo es centro no puede existir un verdadero centro. Allí donde todo emite, el supuesto centro emisor se pierde entre los mensajes entremezclados, en el laberinto de las misivas. Vemos entonces que la era del círculo unitario y de sus sumisos exegetas -el único, el más grande, el que engloba todo lo demás- ha terminado irrevocablemente. La imagen morfológica definidora del mundo poliesférico que vivimos hoy no es ya el globo sino la espuma ${ }^{42}$.

Hoy día, la conexión universal a redes, con todas sus extraversiones en lo virtual, y por ello, no significa estructuralmente tanto una globalización cuanto una espumidificación. En los mundos- espuma -a los que alude Sloterdijk- las 
burbujas aisladas no son introducidas en un hiperglobo único integrador, como sucede en las ideas metafísicas de mundo, sino concentradas en grandes montones irregulares. Con una fenomenología de las espumas intentamos avanzar conceptual y figurativamente hasta una amorfología política que llegue hasta el no-fondo de las metamorfosis y paradojas del espacio solidario en la época de la diversidad de medios y movilidad de mercados mundiales. En tanto que investiga el juego actual de destrucción y nueva conformación de esferas, sólo una teoría de lo amorfo y descentrado podría ofrecer la teoría más íntima y general de la presente época. Espumas, montones, esponjas, nubes y torbellinos sirven como primeras metáforas amorfológicas que ayuden a afrontar las preguntas por las formaciones de mundo interior, las creaciones de contexto y las arquitecturas de inmunidad en la era del desencadenamiento técnico de la complejidad. Lo que actualmente en todos los medios se busca confusamente bajo el nombre de la globalización es, desde el punto de vista morfológico, la guerra universalizada de las espumas.

\section{8.- La patología de las Esferas}

A instancias de la cosa misma, aquí se producen también consideraciones respecto a la patología de las esferas en el proceso moderno-posmoderno. El discurso de una patología de las esferas permite distinguir un foco triple; uno político, en tanto las espumas son estructuras tendencialmente ingobernables que tienden a la anarquía morfológica; uno cognitivo, en tanto los individuos y las asociaciones de sujetos que viven en espumas ya no pueden llegar a formar un mundo global, puesto que la idea misma del mundo global, con su acento característicamente holístico, pertenece inequívocamente a la época ya pasada de los círculos metafísicos de encierro total o monosferas; y uno psicológico, en tanto los individuos aislados pierden tendencialmente en las espumas la fuerza de formación psíquica de espacio y se encogen convirtiéndose en puntos depresivos aislados que son transferidos a un entorno discrecional (llamado sistémicamente con razón medio ambiente, mundo del entorno); tales individuos padecen de aquellas mermas de inmunidad que se producen por la decadencia de las solidaridades -por no hablar por el momento de las nuevas inmunizaciones por participación en creaciones o regeneraciones de esferas. Para las personas privadas, débiles esféricamente, su período de vida se convierte en el cumplimiento auto-diseñado de un encierro en una celda de aislamiento; yoes sin extensión, cuya acción palidece, pobres en participación miran absortos hacia fuera, a través de la ventana de los medios, a movidos paisajes de imágenes. En las fuertes culturas de masas es típico que suceda que las imágenes, por su movilidad, se vuelvan mucho más vivas que la mayoría de sus contempladores: repetición del animismo a la altura de la Modernidad.

De hecho, en la era a-redonda, descentrada, incluso bajo las circunstancias más favorables, el alma ha de hacerse a la idea de que la espuma global híbrida ha de resultar algo impenetrable para las burbujas aisladas, los individuos liberados que se completan a sí mismos, que amueblan mediáticamente sus espacios propios; de todos modos, la navegabilidad puede suplir parcialmente a la transparencia. 
Ciertamente, mientras el mundo como un todo pudo ser divisado panópticamente desde un punto dominante, parecía inteligible por la auto transparencia con la que la esfera divina se iluminaba a sí misma para poseerse plenamente en cada punto; la idea de la participación humana en tales transparencias liberaba formas imperiales y monológicas de razón; el mundo resplandecía como un todo en el brillo de la mirada en redondo que ejercía el dominio desde el centro. Dios mismo no era otra cosa que el centro y el perímetro, a la vez, del globo del ser proyectado y examinado por él, y todo pensar fundado en él participaba analógicamente de la excelsitud de su mirada central. Pero en los mundos de espuma ninguna burbuja puede ampliarse hasta convertirse en el globo absolutamente centrado, omnicomprensivo, anfiscópico; ninguna luz media atraviesa la espuma totalmente en su dinámica turbiedad. Por eso, a la ética de las burbujas descentradas, pequeñas y medianas, en la espuma del mundo, pertenece el esfuerzo de moverse con la prudencia de una modestia sin par en un mundo de una amplitud sin par; en la espuma tienen que producirse juegos racionales discretos y polivalentes que enseñen a vivir con una multiplicidad cambiante de perspectivas y prescindan de la quimera del punto visual único y soberano. Pensar en la espuma es navegar sobre lábiles corrientes; otros dirían que,bajo el efecto de las tareas del pensar, hoy día, se está cambiando hacia una praxis racional plural y transversal.

Con esta ciencia, ni alegre ni triste, de las espumas, el tercer volumen de Esferas ofrece una teoría de la era presente bajo el punto de vista fundamental de que la des-animación lleva una ventaja inalcanzable ya a la re-animación. Es el exterior inanimable lo que da que pensar en la época esencialista moderna. Ese diagnóstico llevaría irremisiblemente a resignarse a la nostálgica añoranza de una imagen del mundo, añoranza que todavía persigue hoy una totalidad viviente en el sentido de una conformación holística. Pues sea lo que sea siempre lo que se afirme como interior aparecerá cada vez con mayor evidencia como el interior de un exterior. No hay dicha segura frente a la endoscopia; en torno a cada célula feliz, íntima, vibrante, pululan bandadas de desilusionadores profesionales: paparazzis del pensar, deconstructivistas, negadores del espacio interior. Una horda de observadores que todo quiere abordarlo desde fuera y que nada sabe de los ritmos interiores. Ni de ritmo alguno: ¿no pertenecemos nosotros mismos desde hace mucho a esta en la mayoría de los ámbitos, en la mayoría de los momentos? Al parecer el mundo se ha hecho demasiado grande para gentes de viejo estilo que aspiran a una comunidad real en que haya cosas cercanas y lejanas. Con lo que apareció tras el horizonte, la hospitalidad de los seres sapiens se ha extendido más allá de su medida crítica. Ninguna institución, aunque se tratara de una iglesia que pensara "Según el todo", "kata holon", y amara universalmente, $\mathrm{y}$, sobre todo, ningún individuo aislado que siga leyendo esforzadamente, puede imaginarse todavía estar lo bastante abierta para todo lo que estimula, habla e interpela; la mayoría de los individuos, lenguajes, obras de arte, mercancías, galaxias, vista desde cada una de las posiciones del mundo de la vida, queda como mundo externo inasimilable, y esto sucede necesariamente y para siempre. Todos los "sistemas", se trate de hogares, comunas, iglesias o estados, y sobre todo de parejas e individuos, están condenados a su específica 
exclusividad; el espíritu del tiempo celebra cada vez más abiertamente su inocente complicidad con lo exterior indeterminado y diverso. La historia del espíritu no es hoy -sino- los juegos finales de la observación externa.

La espacialidad interior animada, que se intenta mostrar en todos los aspectos fundamentales de la existencia y de la cultura humanas, es efectivamente un "realissimum" que se substrae en principio a toda representación geométrica y lingüística -en general a toda representación-, y que, sin embargo, gracias a una potencia de redondeamiento que actúa antes de todas las construcciones circulares formales y técnicas, fuerza en cualquier sitio donde haya un ente algo así como conformaciones originarias de círculos y globos.

Es por ellas, precisamente, por las que los mundos separados de los seres reales que viven en común tienen una dinámica formal redondeada que se produce espontáneamente sin la colaboración de los geómetras. De la auto-organización de los espacios psicocósmicos y políticos surgen metamorfosis del círculo en las que se constituye esférico-atmosféricamente el ser-ahí. La palabra autoorganización -que aquí se utiliza sin la histeria cientificista usual- ha de llamar la atención sobre el hecho de que el círculo que cobija al hombre ni sólo se hace ni sólo se encuentra hecho, sino que, en el límite entre construcción y autorrealización, se redondea él mismo espontáneamente, o mejor dicho: se realiza en aconteceres de redondeamiento, como el que se produce con los reunidos en torno al fuego del hogar, que se agrupan libre y determinadamente en torno al foco de fuego y a las ventajas inmediatas que proporciona el calor que despide. De ahí que el análisis esferológico que se aborda en este primer volumen partiendo de las microformas no sea ni una proyección constructivista de espacios redondeados en los que los seres humanos se imaginen una existencia común, ni una meditación ontológica sobre el círculo en el que estuvieran encerrados los mortales en virtud de un orden trascendente inescrutable.

Así Sloterdijk, como introducción a una poética medial de la existencia, la esferología, en principio, sólo quiere dibujar las conformaciones de inmanencias simples que aparecen en las organizaciones humanas (y extrahumanas), sea como organizaciones de intimidad arcaica, sea como diseño del espacio de pueblos primitivos o como autointerpretación teológico-cosmológica de imperios tradicionales. Por eso, a primera vista, este texto, sobre todo en su segunda parte, podría aparecer también como una historia cultural que con ayuda de conceptos morfológicos, inmunológicos y transferencial-teóricos mostraría, de manera inusual, un modo de ver las cosas que, si todavía no conduce a lo esencial, no sería ni completamente falso ni completamente inoportuno, suponiendo, claro está, que se esté dispuesto a admitir que sólo por la filosofía puede experimentar la inteligencia cómo sus pasiones llegan a conceptos.

\section{9.- Antropotécnicas, sistema de prácticas psico-inmunológicas}


En su más reciente libro, Has de cambiar tu vida ${ }^{43}$, Sloterdijk aborda la historia de los procesos inmunológicos espirituales desde las antiguas tradiciones filosóficas de oriente y occidente hasta internarse en las modernas tecnologías génicas ${ }^{44}$. Sloterdijk en la primera parte de la obra nos pone de frente ante las tradiciones ascéticas de oriente y occidente: ¿pueden haber respuestas a la actual crisis global desde esos ejercicios ascéticos? Leerlo es como conversar con un viejo sabio de voz pausada y profunda. Retomado - ya hacia el final del escrito algunas cuestiones esbozadas en "El hombre operable; Notas sobre el estado ético de la tecnología génica"45, del que me he hecho cargo en el Artículo "Sloterdijk y Nietzsche; Nihilismo, antropogénesis y presagios sobre los últimos hombres". ${ }^{46}$

¿Desde qué luz mirar nuestras decisiones espirituales como seres humanos que cruzamos calles, escampamos de la lluvia o nos refugiamos en nuestras casas? ¿Hacia dónde nos refugiamos? ¿De quién o de qué? ¿Cómo enfrentamos los miedos? Nuestros acercamientos al arte, a la educación, al deporte, a las religiones, ¿qué pueden significar? Ya sea el arte, la religión o los deportes requieren de nosotros un comportamiento ascético, una disciplina, un refrenamiento de las pasiones. ${ }^{47}$

El movimiento que aquí se dice que se despliega lo califica Würtz, consecuentemente, no como una mera compensación, sino como una supercompensación: en él, la reacción iría más allá del impulso inicial ${ }^{48}$.

Alli donde aparezca el ser humano, le antecede su estatus de impedido: ése era el estribillo de los discursos filosóficos sobre el hombre en el siglo pasado, independientemente de que se hable, como lo hace el psicoanálisis, del ser humano como de un mutilado falto de ayuda, que sólo puede llegar a sus metas renqueando, ${ }^{49}$ o de que se le considere, como hacen Bolk y Gehlen, un lisiado

43 SLOTERDIJK, Peter, (2009) Has de cambiar tu vida; sobre Antropotécnica, Editorial PreTextos, Valencia, 2012 Un libro aparecido en este año (2012), cuyo nombre nace de un poema de Rilke a partir del Apolo de Rodin en el Louvre, nos pone de frente ante las tradiciones ascéticas de oriente y occidente: ¿pueden haber respuestas a la actual crisis global desde esos ejercicios ascéticos? Leerlo es como conversar con un viejo sabio de voz pausada y profunda.

$44 \quad$ Retomado algunas cuestiones esbozadas por Sloterdijk en "El hombre operable; Notas sobre el estado ético de la tecnología génica" (2000), Artículo que además de traducir he comentado en el Artículo: "Sloterdijk y Nietzsche; Nihilismo, antropogénesis y presagios sobre los últimos hombres" publicado en PSIKEBA, Revista de Psicoanálisis y Estudios Culturales, de la Universidad de Buenos Aires (UBA), ISSN 1850-339X, Nº 8, 2008.

45 SLOTERDIJK, Peter, "El hombre operable;Notas sobre el estado ético de la tecnología génica, Conferencia tuvo lugar el 19 de mayo de 2000, En Revista Observaciones Filosóficas, Traducción propia.

46 VÁSQUEZ ROCCA, Adolfo, "Sloterdijk y Nietzsche; Nihilismo, antropogénesis y presagios sobre los últimos hombres" publicado en PSIKEBA, Revista de Psicoanálisis y Estudios Culturales, de la Universidad de Buenos Aires (UBA), ISSN 1850-339X, No 8, 2008.

47 CASADIEGO, Benjamin, Recensión de Has de cambiar tu vida de Peter Sloterdijk, julio de 2012 -Publicado por La red Departamental de Bibliotecas del Cesar. <http://caracolidelcesar.blogspot.com/2012/07/de-habitos-y-pasiones.html>

48 SLOTERDIJK, Peter, Has de cambiar tu vida. Sobre antropotécnica, Editorial Pre-Textos, Valencia, 2012, p. 83

49 SCHENEIDER, Peter, Erhinken und erfliegen. Psychoanalytische Zwifel an der Vernunft, 
neoténico- cuya inmadurez crónica sólo es compensable mediante rígidas envolturas culturales- , o como hace Plessner, un discapacitado excéntrico, que está al margen de si mismo y se ve a sí mismo viviendo, o bien, como hacen Sartre y Blumenberg, un discapacitado de la visibilidad, condenado de por vida a entender la desventaja de ser visto por otros ${ }^{50}$.

La dilucidación de este concepto nos llevará, en primer lugar, a explorar brevemente la relación entre antropogénesis y tecnología en Sloterdijk, para luego examinar la doble acepción del concepto antropotécnica en las dos obras mencionadas. Nos referimos a la antropotécnica como "mejora del mundo" (Weltverbesserung) y a la antropotécnica como "mejora de uno mismo" (Selbstverbesserung). Dos acepciones que, como veremos, operan respectivamente una interesante transformación de los conceptos "biopolítica" y "cuidado de sí", que según Sloterdijk quedaron incompletos en la obra de Foucault. Pues según el alemán, una comprensión adecuada del modo en que los hombres gobiernan a otros y se gobiernan a sí mismos sólo es posible a través de un tipo de reflexión a la que Foucault se negó toda su vida: la antropología filosófica. ${ }^{51}$ Dejando de lado las polémicas en torno a su persona, mi lectura de Sloterdijk estará marcada, entonces, por el intento de ver su filosofía como una interesante recuperación y transformación del proyecto foucaultiano, y esto mediante una "puesta al día" de la genealogía nietzscheana. ${ }^{52}$

Sloterdijk desarrolla su pensamiento a partir de conceptos eminentemente antropológicos, cuestión que se observa al atender como sus obras fundamentales discuten la cuestión de la -así llamada- antropogénesis.

Pero aquí nuevamente encontramos a Sloterdijk en medio de una polémica o cuestionamiento filosófico de largo alcance. He aquí la nueva polémica: entre las mayores influencias que recibe Sloterdijk para resolver las cuestiones recién planteadas se encuentra la del sociólogo y filósofo Arnold Gehlen, ${ }^{53}$ figura non

Gotinga, 2001.

50 SLOTERDIJK, Peter, Has de cambiar tu vida. Sobre antropotécnica, Editorial Pre-Textos, Valencia, 2012, p. 83

51 Aquí hay un campo abierto para los estudios sobre los alcances y omisiones de la obra de Foucault. Sloterdijk propone, en cambio,(a diferencia de Foucault y - por cierto de Heidegger y) servir al pensamiento filosófico apoyándose en los conocimientos de la antropología y de las ciencias biológicas en sentido amplio. Pero no se hace cargo de esclarecer o justificar las dificultades metodológicas que esta mezcla de saberes de diverso origen trae consigo. La filosofía de Sloterdijk tiene, por eso, la impronta híbrida que muchos filósofos rechazan en nombre de la clásica estrictez y limpieza de procedimientos que, según ellos, siempre ha caracterizado a la disciplina.

52 "Puesta al día" que ha sido fuertemente criticada por Axel Honneth, para quien Sloterdijk no hace otra cosa que dar vueltas sobre viejos temas, abordados ya por otros.

53 Arnold Gehlen: filósofo y sociólogo alemán, miembro del partido nazi. Sus teorías han inspirado el desarrollo del neoconservadurismo contemporáneo alemán. Sus mayores influencias como estudiante de filosofía fueron Hans Driesch, Nicolai Hartmann y, especialmente, Max Scheler. Se unió en 1933 al partido Nazi, y tuvo una brillante carrera como miembro de la escuela de Leipzig, bajo la tutela de Hans Freyer. Reemplazó a Paul Tillich, quien había emigrado a Estados Unidos, en la Universidad de Frankfurt. Desde su puesto de profesor, Gehlen criticó los movimientos de protesta desarrollados en la última parte de la década de los años 1960. La filosofía de Gehlen fue una fuerte influencia para muchos pensadores alemanes neoconservadores 
sancta en Alemania por haber sido miembro del Partido Nacionalsocialista y luego un crítico acervo del movimiento estudiantil del 68. En escritos tales como El hombre: su naturaleza y su lugar en el mundo ${ }^{54}$, de 1940, y El hombre en la era de la tecnología, de $1957^{55}$, Gehlen desarrolla la célebre tesis del hombre como Mängelwesen, como "ser deficitario". Parte del supuesto de que el hombre es un ser orgánicamente "desvalido", es decir que no está dotado por la naturaleza con órganos especializados capaces de adaptarse al medio ambiente. No tiene, como otros animales, órganos de ataque, de defensa o de huida. No está revestido de pelaje ni preparado para la intemperie, carece de alas para volar, etc. Frente a esta "falta de especialización" orgánica, el animal hombre se ve obligado, para sobrevivir, a devenir un "ser cultural". Lo cual significa que ante la imposibilidad orgánica de adaptarse al medio ambiente, debe crear un medio ambiente artificial que le permite producirse a sí mismo con relativa independencia del mundo orgánico. Así, pues, siendo el hombre un ser carencial por naturaleza, incapaz de adaptarse a ningún ambiente natural, debe fabricarse una "segunda naturaleza", un mundo artificial sustitutivo que compense su deficiente equipamiento orgánico (Gehlen 1993).

Es en este punto donde la técnica cumple un papel fundamental. En vista de su constitución biológica, el hombre no podría conservarse dentro de la naturaleza tal como ésta es, de primera mano, sino que se ve abocado a emprender una modificación práctica de cualquier realidad natural con la que se encuentra. El concepto Techné es utilizado por Gehlen para indicar la destreza, la competencia, el entrenamiento y la habilidad alcanzados por los hombres para construir una "naturaleza segunda", una "sobrenaturaleza", como la llamaba Ortega y Gasset ${ }^{56}$. No es posible para el hombre sobrevivir sin la ejercitación organizada y metódica que le permita operar con eficiencia en contra de la naturaleza interna y externa. Sin el desarrollo de una serie de prácticas coordinadas y disciplinadas, sin la pericia y la especialización, el animal humano habría sido barrido fácilmente por el

contemporáneos. Conceptos de su obra, como Reizüberflutung o "sobreabundancia de estímulos", y desinistitucionalización (post-historia o fin de la historia), véase Kojève, Jünger, Adorno, han ganado amplio consenso en Alemania. En 1938 aceptó el cargo de profesor en la Universidad de Königsberg y en 1940 en la Universidad de Viena, en donde enseñó hasta ser llamado a filas por la Wehrmacht en 1943.

54 GEHLEN, Arnold, Título original en alemán: Der Mensch. Seine Natur und seine Stellung in der Welt.

55 Para vivir en regiones heladas, por ejemplo, el hombre primitivo carecía ciertamente de dotación natural, pero pudo calentarse con fuego y envolverse en pieles de las que él mismo carecía. Sin embargo, ello supuso el desarrollo de una techné que le permitió generar habi-lidades para cazar animales más grandes, producir artificialmente fuego y fabricar herramientas especiales.

56 Ortega y Gasset ya se había pronunciado en términos muy similares en su Meditación de la Técnica. Para él: el hombre, merced a su don técnico, hace que se encuentre siempre en su derredor lo que ha menester -crea, pues, una circunstancia nueva más favorable, segrega, por decirlo así, una sobrenaturaleza adaptando la naturaleza a sus necesidades .Y a continuación mantenía una tesis fundamental para reflexionar sobre la tecnología: la técnica es lo contrario de la adaptación del sujeto al medio, puesto que es la adaptación del medio al sujeto. Ya esto bastaría para hacernos sospechar que se trata de un movimiento en dirección inversa a todos los biológicos. 
devenir de una naturaleza hostil para la que no estaba preparado (Gehlen). ${ }^{57} \mathrm{La}$ técnica, en este caso, no son las herramientas que el hombre fabrica, sino el conjunto de acciones coordinadas, estratégicas, reglamentadas y orientadas al logro de una finalidad precisa. Podríamos decir que la técnica es producto de la inteligencia práctica del hombre, aquella que le permite "disponer" del entorno y someter-lo a sus necesidades vitales. No es, entonces, que el hombre haga "uso" de la técnica, sino que el hombre es, en sí mismo, un animal técnico. La técnica no es algo agregativo sino constitutivo del animal humano. O para decirlo de otro modo: a consecuencia de su infradotación orgánica, el hombre se ve abocado a pensar y actuar técnicamente. Y es esta habilidad compensatoria lo que le permitió devenir "Homo sapiens" (Gehlen). ${ }^{58}$

\section{0.- El "homo immunologicus" y el Arte de la Educación: entre las pasiones y los hábitos.}

El héroe de esta historia, el homo immunologicus, que ha de dar una armadura simbólica a su vida, con todos sus peligros y sus excedentes, es el hombre que lucha consigo mismo, preocupado por su propia forma. Lo caracterizaremos más de cerca como el hombre ético.

La confusión de base tanto de la ética griega como del arte de la educación perteneciente a ella surge de la circunstancia de que nunca estuvo en condiciones de elaborar con la claridad necesaria la diferencia entre pasiones (Daímon) y hábitos (Ethos), por lo que tampoco conceptualizó nunca claramente la correspondiente distinción entre dominación y ejercicio. Las consecuencias quedarían de manifiesto en la ambigüedad, de más de dos milenios, de la pedagogía europea. Ésta abogó con frecuencia, al principio mediante una disciplina basada en la dominación, a sus educandos tratándolos como a inferiores, para terminar dirigiéndose a ellos, cada vez más frecuentemente, como a falsos adultos exentos de toda disciplina y del esfuerzo del ejercicio. Que los alumnos son en primer lugar y la mayoría de las veces, atletas en ciernes, por no decir acróbatas, a los que se trata de poner en forma nunca quedó patente con la explicitud que se debe a una cosa tan importante, a causa de la mistificación moralista y política de la pedagogía. Así la diferenciación entre estas dos magnitudes (pasiones y hábitos) llevó en la historia del pensamiento a múltiples confusiones éticas y biopolíticas.

La acrobacia aquí supuesta es una disciplina que cruza de manera transversal el

57 Para vivir en regiones heladas, por ejemplo, el hombre primitivo carecía ciertamente de dotación natural, pero pudo calentarse con fuego y envolverse en pieles de las que él mismo carecía. Sin embargo, ello supuso el desarrollo de una techné que le permitió generar habi-lidades para cazar animales más grandes, producir artificialmente fuego y fabricar herramientas especiales.

58 GEHLEN, Arnold, Antropología filosófica. Del encuentro y descubrimiento del hombre por sí mismo. Barcelona: Paidós, 1993. 
libro Has de cambiar tu vida. El acróbata es aquél que luego de ejercicios rigurosos logra realizar maniobras riesgosas, al filo de la vida, sin que los espectadores accedan a la dificultad, oculta tras una sonrisa de seguridad. Cuatro ejemplos de acróbatas, además de todos los circos del que el autor parece ser asiduo, están: Kafka, del cual se analiza su cuento Un artista del hambre ${ }^{59}$, Nietzsche, Emile Cioran y Wittgenstein. "Mientras las pasiones requieren un freno, los hábitos tienen que construirse con adiestramientos y ejercicios bastante largos, crecen mediante un comportamiento de repetición mimético, para convertirse, a partir de un determinado punto de su desarrollo, en un empeño propio apoyado en la voluntad del sujeto.

Con todo, por muy elemental que parezca la diferenciación entre hábitos y pasiones, la asociación de estas dos magnitudes lleva en la historia del pensamiento ético a múltiples confusiones".

Dos errores de la ética primigenia de la filosofía europea: el primero confundiría el refrenamiento de las pasiones con la expulsión de demonios inferiores. El segundo confundiría la superación de los malos hábitos con la iluminación por parte de espíritus superiores. Los representantes del primer camino: las corrientes estoicas y gnósticas, con su inclinación a la evasión hacia un mundo superior. Del segundo: las tradiciones platónicas y místicas, con su inclinación a la mortificación de la carne o a sobrevolar por encima de la experiencia corporal. Dos corrientes fuertes dentro de la cultura occidental, pero, por fortuna, no las principales. "El hecho de que estos caminos no se convirtieran en las corrientes principales se lo debemos a la resistencia de las éticas pragmáticas, ayudadas por la sabiduría anónima de la cultura de la cotidianidad. Estas dos son las fuentes de donde bebe la herencia del saber europeo sobre el arte de vivir".

¿Somos solidarios como raza? ¿Somos altruistas? Simplemente nos protegemos de los demás, llámese vecino hostil, compañero de trabajo, país, empresa. Nuestra solidaridad hace parte de las estrategias de supervivencia: hoy por ti mañana por mí. Nuestras sociedades, como un organismo biológico se protegen entre sí. "Toda la historia es la lucha entre sistemas inmunológicos".

La inmunidad biológica hace referencia al plano del organismo individual, relacionada formalmente con los dos sistemas inmunológicos sociales: el sistema solidario y el simbólico. "El primero garantizaría la seguridad jurídica, la asistencia existencial y los sentimientos de parentesco, más allá de las respectivas familias. El sistema simbólico depararía una seguridad en la imagen del mundo, una compensación de la certeza de la muerte ${ }^{60}$ y una constancia de las normas que abarca generaciones. Estos sistemas, al igual que los biológicos pueden pasar

59 KAFKA, Franz, La Condena, Cuento "Un artista del hambre", Ed. Emece, Buenos Aires, 1989.

60 VÁSQUEZ ROCCA, Adolfo, "Sloterdijk; espacio tanatológico, duelo esférico y disposición melancólica", La Lámpara de Diógenes: Revista de Filosofía. Número doble, Año 8, Números 14 y 15, Vol. 8, pp. 179-188. Enero - junio 2007 / Julio - diciembre 2007 | ISSN 1665-1448. (bi-annual) Seccion D, No. 16, Col. Unidad Gudalupe, Puebla, PUE. CP 72560, México; Revista registrada en PHILOSOPHER'S INDEX | website: http://www.Idiogenes.buap.mx/ <http://www.Idiogenes.buap.mx/revistas/14/179.pdf> 
etapas de debilidad o de fracaso. Su colapso, al igual que el biológico significaría el colapso de la colectividad". ${ }^{61}$

\section{1.- La autoproducción del hombre.}

Por un momento, el programa ético del presente había aparecido con nitidez en el campo de visión, cuando Marx y los jóvenes hegelianos articularon la tesis de que es el propio hombre el que produce al hombre. Lo que decía esta afirmación quedó, en un abrir y cerrar de ojos, figurado por otro parloteo, que hablaba del trabajo como la única acción esencial del ser humano. Pero si el hombre produce, de hecho, al hombre, no es precisamente a través del trabajo y de sus resultados concretos, como tampoco mediante el recientemente tan encomiado "trabajo del hombre en sí mismo" y menos por la "interacción" o la "comunicación", invocadas como alternativas. Eso lo hace el hombre viviendo su vida en diversas formas de ejercicio.

Defino como ejercicio cualquier operación mediante la cual se obtiene o se mejora la cualificación del que actúa para la siguiente ejecución de la misma operación, independientemente de que se declare o no se declare a ésta como un ejercicio.62

Quien hable de la autoproducción del hombre sin mencionar su configuración en la vida que se ejercita ha errado el tema desde el principio. En consecuencia, hemos de dejar prácticamente en suspenso todo lo que haya sido sobre el hombre como un ser trabajador, para traducirlo en el lenguaje de la ejercitación de la vida o de un comportamiento que se configura y acrecienta a sí mismo. Y no sólo el fatigado homo faber -que objetiviza el mundo según su modo de "hacer"- ha de desocupar el sitio que tenía en el centro de la escena lógica, sino que incluso el homo religiosus, vuelto con ritos sub-reales hacia el mundo del más allá, deberá aceptar la retirada que se merece, tanto el hombre trabajador como el creyente son englobados en $\mathrm{n}$ nuevo concepto general. Ya es tiempo de desenmascarar al hombre como un ser vivo surgido por la repetición. Así como el siglo XIX estuvo, en lo cognitivo, bajo el signo de la producción y el siglo $X X$ bajo el de la reflexividad, el futuro debería ser presentado bajo el signo del ejercicio.

Nietzsche presentó, en sus reflexiones dietológicas de la decada de 1880 piénsese en las páginas correspondiente de su escrito de autocrucifixión Ecce homo-, planteamientos para una ascetología general ${ }^{63}$. Por mucho que éstos

61 SLOTERDIJK, Peter, (2009) Has de cambiar tu vida; sobre Antropotécnica, Editorial PreTextos, Valencia, 2012, pp. 16-17

62 Explicaciones sobre el concepto de ejercicio podrán encontrarse más tarde, en los apartados de mi escrito sobre el descubrimiento de la pedagogía [pág.256 sigs., apartado "Antropotécnica: volver el poder de la repetición"], sobre la constitución del hábito [pág. 238 sigs., apartado "Del genio de la costumbre: Aristóteles y Tomás de Aquino"] o sobre el circulus virtuosus [pág. 407 sigs., apartado "Actuación autoplástica: circulus virtuosus"], así como en las tres primeras secciones del capítulo 12 [pág. 515 sigs., apartado "Ejercicios y ejercicios fallidos" y sigs.].

63 SLOTERDIJK, Peter, (2009) Has de cambiar tu vida; sobre Antropotécnica, Editorial Pre- 
hayan sido malentendidos por parte de lectores superficiales como un repliegue de la filosofía a un nivel farmacéutico.64

De momento es difícil indicar desde ahora las consecuencias de estas reflexiones para el ámbito de lo humano. De momento es suficiente constatar que la continuación de la evolución biológica en lo social y en lo cultural lleva a una categoría superior de los sistemas inmunológicos. Tenemos razones para no contar en el hombre con un único sistema inmunitario, el biológico, el cual, estando como está en el aspecto evolutivo en primer lugar, en la historia de los descubrimientos humanos se encontraría, sin embargo, en el último ${ }^{65}$. En la esfera humana existen no menos de tres sistemas inmunitarios, los cuales trabajan superpuestos, con un fuerte ensamblaje cooperativo y una complementariedad funcional. Sobre el sustrato biológico, en gran parte automatizado e independiente de la conciencia, se han ido desarrollando en el hombre, en el transcurso de su desarrollo mental y sociocultural, dos sistemas complementarios encargados de una elaboración previsora de los daños potenciales: por un lado, un sistema de prácticas socio-inmunitarias, especialmente las jurídicas o las solidarias, pero también las militares, con las que los hombres desarrollan, en la "sociedad", sus confrontaciones con agresores ajenos y lejanos y con vecinos ofensores 0 dañinos;66 por otro lado, un sistema de prácticas simbólicas, o bien psicoinmunológicas, con cuya ayuda los hombres logran, desde tiempos inmemoriales, sobrellevar más o menos bien su vulnerabilidad ante el destino, incluida la mortalidad, a base de antelaciones imaginarias y del uso de una serie de armas mentales.67 Es irónico en estos sistemas el que sean susceptibles de recibir una explicación de su lado oscuro, aunque existan, desde el principio, como algo dependiente de la conciencia y se tengan por magnitudes auto-transparentes. No funcionan a espaldas de los sujetos, sino incrustados por completo en su comportamiento intencional; no obstante, es posible que entendamos ese comportamiento mejor de como es entendido por sus propios ingenuos agentes. $Y$ porque esto es así es posible una ciencia de la cultura, y la ciencia de la cultura es necesaria porque el trato no ingenuo con los sistemas inmunitarios simbólicos se

Textos, Valencia, 2012, p. 19.

64 Típico es, en este aspecto, Oswald Spengler, en su obra Der Untergang des Abendlandes, Múnich, 1979, pág.462 (trad. Cast.: La decadencia de Occidente, 2 vols., trad. De Manuel García Morente, RBA, Barcelona 2005), al querer reconocer en el giro de Nietzsche hacia la conciencia del arte de la vida un síntoma del "climaterio de la cultura" (ibid., pág. 459). Veía ahí un ejemplo de la decadencia que, según él, caracteriza el estadio "civilizatorio" de las culturas, en el transcurso del cual las elevadas visiones metafísicas del mundo degeneran en instrucciones de uso dirigidas al individuo en sus preocupaciones cotidianas y digestivas.

65 SLOTERDIJK, Peter, (2009) Has de cambiar tu vida; sobre Antropotécnica, Editorial PreTextos, Valencia, 2012, p. 23

66 Sobre el "sistema jurídico como sistema inmunitario del sistema social" cf. Niklas Luhmann, Soziale Systeme. Grundriss einer allgemeinen Theorie, Fráncfort, 1984, pág. 509 sig. (trad. Cast.:Sistemas sociales: lineamientos para una teoría general, trad. De Silvia Pappe, Brunhilde Erker, Javier Torres, Anthropos, Barcelona, 1998).

67 Con problemas de este tipo se ve confrontada, entre otras, la nueva ciencia de la psicoinmunología, que se ocupa del ensamblaje de varios sistemas de mensajeros químicos (sistema nervioso, sistema hormonal, sistema inmunitario). 
ha convertido hoy dís en una condición de supervivencia de las propias "culturas".68

Sloterdijk se concentra principalmente en las manifestaciones del tercer nivel inmunitario. Reúne materiales para la biografía del "homo immonologicus", dejándose guiar por la hipótesis de que es especialmente aquí donde se ha de encontrar el entramado de donde surgen las antropotécnicas. Entiende, con esta última expresión, los procedimientos de ejercitación, físicos y mentales, con lo que los hombres de las culturas más dispares han intentado optimizar su estado inmunológico frente a los vagos riesgos de la vida y las agudas certezas de la muerte.

\section{NOTA BIOGRÁFICA}

Adolfo Vásquez Rocca. Doctor en Filosofía por la Pontificia Universidad Católica de Valparaíso; Postgrado Universidad Complutense de Madrid, Departamento de Filosofía IV, mención Filosofía Contemporánea y Estética. Profesor de Postgrado del Instituto de Filosofía de la Pontificia Universidad Católica de Valparaíso; Profesor de Antropología y Estética en el Departamento de Artes y Humanidades de la Universidad Andrés Bello UNAB. Profesor de la Escuela de Periodismo, Profesor Adjunto Escuela de Psicología y de la Facultad de Arquitectura UNAB Santiago. Profesor PEL Programa Especial de Licenciatura en Diseño, UNAB DUOC UC - En octubre de 2006 y 2007 es invitado por la 'Fundación Hombre y Mundo' y la UNAM a dictar un Ciclo de Conferencias en México. - Miembro del Consejo Editorial Internacional de la 'Fundación Ética Mundial' de México. Director del Consejo Consultivo Internacional de 'Konvergencias', Revista de Filosofía y Culturas en Diálogo, Argentina. Miembro del Consejo Editorial Internacional de Revista Praxis - Facultad de Filosofía y Letras, Universidad Nacional UNA, Costa Rica. Miembro del Conselho Editorial da Humanidades em Revista, Universidade Regional do Noroeste do Estado do Rio Grande do Sul, Brasil y del Cuerpo Editorial de Sophia -Revista de Filosofía de la Pontificia Universidad Católica del Ecuador-. -Secretario Ejecutivo de Revista Philosophica PUCV. -Asesor Consultivo de Enfocarte -Revista de Arte y Literatura- Cataluña / Gijón, Asturias, España. -Miembro del Consejo Editorial Internacional de 'Reflexiones Marginales' -Revista de la Facultad de Filosofía y Letras UNAM. -Editor Asociado de Societarts, Revista de artes y humanidades, adscrita a la Universidad Autónoma de Baja California. -Miembro del Comité Editorial de International Journal of Safety and Security in Tourism and Hospitality, publicación científica de la Universidad de Palermo. -Miembro de la Federación Internacional de Archivos Fílmicos (FIAF)

68 SLOTERDIJK, Peter, (2009) Has de cambiar tu vida; sobre Antropotécnica, Editorial PreTextos, Valencia, 2012. Sobre el significado de supervivencia de la ciencia de la cultura en el contexto global puede verse el capítulo "Perspectiva. El imperativo absoluto", pág. 562 siguientes. 
con sede en Bruselas, Bélgica. Director de Revista Observaciones Filosóficas. Profesor visitante en la Maestría en Filosofía de la Benemérita Universidad Autónoma de Puebla. - Profesor visitante Florida Christian University USA y Profesor Asociado al Grupo Theoria - Proyecto europeo de Investigaciones de Postgrado -UCM. Eastern Mediterranean University - Academia.edu. Académico Investigador de la Vicerrectoría de Investigación y Postgrado, Universidad Andrés Bello. -Investigador Asociado y Profesor adjunto de la Escuela Matríztica de Santiago -dirigida por el Dr. Humberto Maturana. Consultor Experto del Consejo Nacional de Innovación para la Competitividad (CNIC)- Artista conceptual. Crítico de Arte. Ha publicado el Libro: Peter Sloterdijk; Esferas, helada cósmica y políticas de climatización, Colección Novatores, $N^{\circ} 28$, Editorial de la Institución Alfons el Magnànim (IAM), Valencia, España, 2008. Invitado especial a la International Conference de la Trienal de Arquitectura de Lisboa | Lisbon Architecture Triennale 2011. Traducido al Francés - Publicado en la sección Architecture de la Anthologie: Le Néant Dans la Pensée Contemporaine. Publications du Centre Français d'Iconologie Comparée CFIC, Bès Editions , París, (C) 2012

\section{BIBLIOGRAFÍA}

- $\quad$ SLOTERDIJK, Peter, Esferas I, Cap. 2: "Entre rostros. Sobre la emergencia de la esfera íntima interfacial", Editorial Siruela, Madrid, 2003 Siruela,

SLOTERDIJK, Peter, Esferas I - II - III; (1998); (1999); (2004); Madrid;

- SLOTERDIJK, Peter, En el mismo barco. Ensayo sobre la hiperpolítica. Ediciones Siruela, Madrid, 1994.

- SLOTERDIJK, Peter, Sloterdijk, "Actio in Distans; Sobre los modos de formación teleracional del mundo". En Nómadas $N^{\circ}$ 28. IESCO, Instituto de Sociales Contemporáneos, UC, Universidad Central, Bogota: Colombia. Abril, 2008. 

2003,

SLOTERDIJK, Peter, Experimentos con uno mismo, Pre-Textos, Valencia, MATURANA, Humberto, Origen de lo Humano en la Biología de la intimidad. Ed. Instituto de Terapia Cognitiva, Santiago.

MATURANA, Humberto, Desde la Psicología a la Psicología, Cap. "Lenguaje y realidad; el origen de lo humano", p. 96 - 106, Editorial Universitaria, Santiago, 2008. Conferencia organizada por la Sociedad DE Biología de Chile, 3 de noviembre de 1988, Club de Providencia. Publicado originalmente en Arch. Biol. Med. Exp.,. No. 22, pp. 77-81, 1989.

\section{Venecia.}

MATURANA, Humberto, Verden-Zoller, G. Amore e Gioco. Ed. Marsilio, MATURANA, Humberto. Sentido de Lo Humano, JC SAEZ Editor, Santiago, 2003.

- $\quad$ NANCY, Jean- Luc, Ser Singular Plural, Arena Libros, Madrid, 2006

- $\quad$ BILZ, Rudolf, “Sobre la participación emocional. Una contribución al problema del ser humano en su entorno", En R. B., Die unbewältigte Vergangenheit des Menschengeschlechts. Beiträge zu einer Paläoanthropologie, Frankfurt 1967.

- AUGÉ, Macr ; Le sens des autres, París, Le Seuil, 1994. [Trad. Cast. de Charo Lacalle y José Luis Fecé, El sentido de los otros: actualidad de la antropología, Barcelona, Paidós, 1996.

- VÁSQUEZ ROCCA, Adolfo, "Sloterdijk; Antropología de las comunicaciones, concierto de transferencias e historia de la fascinación de proximidad", LA LÁMPARA DE DIÓGENES: Revista de Filosofía. Número doble, Año 8, Números 16 y 17, Vol. 8 Enero - junio 2008 / Julio - diciembre 2008, pp. 119-135 | ISSN 1665-1448. (bi-annual) Seccion D, No. 16, Col. Unidad Gudalupe, Puebla, PUE. CP 72560, México; Revista registrada en PHILOSOPHER'S INDEX | website:

http://www.Idiogenes.buap.mx/revistas/16/119.pdf

http://www.ldiogenes.buap.mx/

- VÁSQUEZ ROCCA, Adolfo, "Sloterdijk; Secretos bizarros de Freud, discretas obsesiones telecomunicativas y primeras formaciones de psicología profunda europea", En NÓMADAS, Revista Crítica de Ciencias Sociales y Jurídicas - Universidad Complutense de Madrid, NÓMADAS. 31 | Julio$\begin{array}{llllll}\text { Diciembre.2011 } & \text { (I), } & \text { pp. } & 339 & - & 368\end{array}$ http://www.ucm.es/info/nomadas/31/adolfovasquezrocca_2.pdf

- VÁSQUEZ ROCCA, Adolfo, "Sloterdijk, Heidegger y Jean-Luc Nancy: Esferas, arqueología de lo íntimo, morfología del espacio compartido e historia de la fascinación de proximidad", En NÓMADAS, Revista Crítica de Ciencias Sociales y Jurídicas - Universidad Complutense de Madrid, NÓMADAS. 32 - JulioDiciembre. $2011 \quad$ (II), http://www.ucm.es/info/nomadas/32/adolfovasquezrocca.pdf

- VÁSQUEZ ROCCA, Adolfo,, Peter Sloterdijk; Esferas, helada cósmica y 
políticas de climatización, Colección Novatores, № 28, Editorial de la Institución Alfons el Magnànim (IAM), Valencia, España, 2008. 221 páginas | I.S.B.N.: 97884-7822-523-1 